НОЧВИНА Белла Анатольевна - кандидат исторических наук, доцент кафедры истории, регионоведения и журналистики Нижегородского государственного лингвистического университета им. Н.А. Добролюбова (603155, Россия, г. Нижний Новгород, ул. Минина, 31a; bella.nochtvina@mail.ru)

\title{
СОВРЕМЕННЫЕ АMЕРИКАНО-ГЕРМАНСКИЕ ОТНОШЕНИЯ: КРИЗИС СТРАТЕГИЧЕСКОГО СОТРУДНИЧЕСТВА
}

Аннотация. Данная статья посвящена анализу современной стратегии взаимного сотрудничества Германии и США в условиях обострения ситуации в сфере ядерного разоружения и стратегической стабильности. Ряд европейских стран оценивают современную внешнеполитическую политику ФРГ как угрозу немецкого гегемонизма в Европе. В статье рассматривается потенциал эффективности внешнеполитической доктрины ФРГ, предпринята попытка оценки перспективы обеспечения Германией своей экономической безопасности в рамках кризиса модели евро-атлантизма и оптимальных средств ее реализации. Автор дает анализ возможности американо-германского диалога в области стратегического сотрудничества, а также трансформации модели внешнеполитического курса ЕС в целом.

Ключевые слова: национальная безопасность, стратегическое партнерство, евро-атлантизм, гегемонизм, мировая экономика

На сегодняшний момент США и Германию связывают не только союзнические отношения по блоку НАТО, но и многочисленные двусторонние договоренности. С момента создания ФРГ становится главным проводником американской политики в континентальной Европе. Отчасти это можно объяснить полузависимым положением «канцлерской демократии», но основным выражением этой политики, на наш взгляд, являлся принцип евро-атлантизма. Провозглашенный еще в эпоху Аденауэра, данный принцип становится основополагающим направлением внешней стратегии ФРГ. Сейчас, по мнению ряда исследователей, политика евро-атлантизма переживает серьезный концептуальный кризис. Традиционный атлантизм вступает в противоречие с интеграционными вызовами европейской безопасности, с изменением роли ЕС в постбиполярном мире, со стремлением европейских стран усилить свою самостоятельность в принятии внешнеполитических решений и тем самым упрочить свои позиции как актора мировой политики.

С приходом к власти в США администрации президента Д. Трампа концептуальный кризис евро-атлантизма только усилился: протекционистская экономическая политика США привела к «торговым войнам» с европейскими партнерами, и прежде всего с ФРГ; стремление Вашингтона расширить поставки американского СПГ в Европу усилило внутренний раскол ЕС, обусловило рост напряженности в отношениях между США и РФ в связи с антироссийскими санкциями, заложниками которых становятся крупные европейские компании, и т.д.

Совсем недавно глава немецкого МИДа Х. Маас выступил с предложением о создании Европейского союза по безопасности и обороне, тем самым поддержав инициативу французского президента Э. Макрона по обеспечению безопасности ЕС собственными силами. Однако в реальности это вряд ли осуществимо: препятствием в реализации военной составляющей европейской безопасности является членство Германии в НАТО (серьезно о выходе ФРГ из Североатлантического альянса немецкое правительство никогда не заявляло). Вторым препятствием становится ряд существенных разногласий между ключевыми партнерами данной инициативы - Германией и Францией, что вносит 
трудности в создание конкретного выражения единой военной стратегии ЕС. И в-третьих, это усиление проамериканских настроений в странах ЦВЕ: если Германия отказывается увеличить военные расходы в Альянсе, то такие страны, как Польша, настаивают на увеличении контингента НАТО на своей территории, видя в самостоятельности немецкой внешнеполитической стратегии угрозу немецкого гегемонизма в Европе.

Линией раскола в американо-германских отношениях в Европе стало размежевание сил в Вышеградской группе. На фоне общеевропейских антироссийских санкций Чехия, Венгрия, Словакия занимают более сдержанную и осторожную позицию в отношении России, что сближает их интересы с интересами Германии. Напротив, Польша и страны Прибалтики требуют более жесткого антироссийского курса ЕС, поддерживая почти все внешнеполитические инициативы США.

Выход США, а затем и РФ из договора ДРСМД поставил европейские страны перед угрозой не только новой гонки вооружений, но и того, что при возможной эскалации конфликта между США и Россией главной буферной зоной станет ЦВЕ.

Отношения союзнического сотрудничества, или стратегического партнерства предполагают реализацию взаимодействия для получения оптимального результата для обеих сторон, что зафиксировано в ст. 2 и 5 устава НАТО [Троицкий 2004: 45]. Проблема отношений США со своими европейскими союзниками состоит в том, насколько стратегия долгосрочного обоюдовыгодного сотрудничества совместима с европейской стратегией автономизации и каковы рамки современной атлантической солидарности.

Даже в условиях формирования нового мирового порядка степень зависимости Европы от США еще достаточно велика, но необходимо учитывать и изменение роли объединенной Германии в постбиполярном мире. Современная Германия пытается изменить вектор стратегического партнерства с США с проамериканского патернализма на режим наибольшего благоприятствования. Американо-германские отношения связывает единый фундамент целей и задач внешнеполитической стратегии, что наглядно доказывает единство позиций США и ФРГ в украинском кризисе. В условиях вызовов глобализации институциональный механизм стратегического сотрудничества между США и Европой только укрепился, однако европейские страны настаивают на большей взаимодополняемости стратегического партнерства ${ }^{1}$. Сегодня Германия является не только сильной экономической державой, лидером ЕС, но и играет важную роль в делах глобализации мирового рынка и мировой политики [Воробьева 2000: 267].

Экспортоориентированная экономика ФРГ составляет серьезную конкуренцию американской экономике, особенно в автомобильной индустрии. Пересечение интересов Германии и США наблюдается и в АзиатскоТихоокеанском регионе, традиционно считавшемся американскими политиками исключительной зоной своих интересов. Возвышение Китая на мировом рынке не ослабило конкуренцию между ЕС и США. ФРГ, являясь экономическим лидером Европейского союза, идентифицирует себя как выразителя общих европейских интересов, а значит вынуждена занимать четкую и жесткую позицию в защите европейской экономической безопасности [US-German... 2003: 112].

\footnotetext{
1 Rede des deutschen Bundeskanzlers, Gerhard Schröder, zum Militäreinsatz gegen Terrorismus und zur Vertrauensfrage am 16. November 2001 vor dem Deutschen Bundestag in Berlin. - Internationale Politik. 2001. № 12. Доступ: http://gerhard-schroeder.de/2001/11/16/vertrauensfrage-afghanistaneinsatz/ (проверено 23.03.2019).
} 
Еще одним примером ухудшения современных германо-американских отношений являются действия США в ситуации со строительством газопровода «Северный поток-2». Действия посла США в Германии Ричарда Гренелла вызывают у ряда видных политиков ФРГ негодование и раздражение: в частности, вице-председатель СДПГ В. Кубикки обвинил Гренелла во вмешательстве во внутренние дела Германии: «Если американский дипломат ведет себя как верховный комиссар оккупационных властей, ему придется узнать, что наша толерантность имеет границы» ${ }^{1}$.

Правительство А. Меркель неоднократно заявляло, что строительство новой ветки газопровода «Северный поток» - это только экономический проект, который не является итогом политического сближения позиций ФРГ и РФ. В ходе дальнейших переговоров с США Германия согласилась на строительство в стране терминала для приема американского сжиженного природного газа, а также подтвердила сохранение транзита поставок газа через Украину. Однако цель стратегии администрации Д. Трампа - максимальное вытеснение России с европейского энергетического рынка, в связи с чем США продолжают давление на своих союзников, угрожая ввести ограничения на европейские компании, которые участвуют в проекте реализации «Северного потока-2» в рамках закона «О противодействии противникам Америки посредством санкций».

В самой Германии возможность введения американских санкций оценивают по-разному. Одни считают, что «с точки зрения внешней политики “Северный поток-2” - катастрофа для Германии» 2 , другие отмечают, что в обеспечении собственной энергетической безопасности правительство ФРГ не остановят ни мнение Европарламента, ни санкции США, ни желание ряда стран Северно-Восточной Европы помешать реализации строительства газопровода, что «угрозы Вашингтона в адрес Германии - признак слабости. Слабость Вашингтона сводится к тому, что США не могут рисковать открытой конфронтацией с Германией, потому что любая такая конфронтация ускорит сближение Берлина с Москвой»3.

На сегодняшний момент Германия придерживается общей стратегии европейской безопасности, диверсификации энергетического рынка ЕС, которая базируется на политике децентрализации, декарбонизации и диджитализации. По оценке генерального секретаря Мирового энергетического совета Кристофа Фрая, строительство газопровода «Северный поток-2» является одним из выгодных вариантов в обеспечении европейской энергетической безопасности: «Необходимо сбалансировать две вещи. Первый вопрос, который можно задать хорошо ли для Европы получить самый дешевый из возможных газ. И “Северный поток-2” обещает предоставлять такой газ для Европы. В контексте того, что Европахочетувидетьразнообразиевпоставкахидешевыйгаз, “Северныйпоток-2” является одним из элементов, который может дать такой дешевый газ, который может быть использован для замены угля, для многих вещей в Европе» ${ }^{4}$

\footnotetext{
1 Немецкие депутаты потребовали изгнать из страны американского посла. Доступ: http://www.trud. ru/article/19-03-2019/1373747_nemetskie_deputaty_potrebovali_izgnat_iz_strany_amerikanskogo_posla. html (проверено 23.03.2019).

2 Zeit: «Северный поток - 2» для Германии - политическая катастрофа, но останавливать его не нужно. Доступ https://russian.rt.com/inotv/catalog/channel/Die\%20Zeit/2018/12/07 (проверено 23.03.2019).

3 США не осилят еще одну конфронтацию: почему Трамп не способен навредить американогерманским отношениям? Доступ https://news-front.info/2019/02/20/ssha-ne-osilyat-eshhe-odnukonfrontatsiyu-pochemu-tramp-ne-sposoben-navredit-amerikano-germanskim-otnosheniyam/ (проверено 23.03.2019).

4 Кристоф Фрай: Россия всегда будет энергетической сверхдержавой. Доступ: https://ria. ru/20190324/1552042092.html (проверено 23.03.2019).
} 
В этой связи интересными становятся истинные причины выступлений правительства Польши против строительства газопровода. Известно, что Польша является главным американским союзником в ЦВЕ. Недавно польское правительство заключило соглашение о покупке американских противоракетных комплексов «Патриот», а также выступило с предложением строительства на территории Польши военной базы НАТО «Форт Трампа». Выступая против «Северного потока-2», Польша проводит не столько антироссийскую, сколько антинемецкую политику. В частности, Польша подписала соглашение о создании балтийского газопровода, который должен осуществлять поставки газа из Норвегии через Данию в Польшу, и стремится сохранить себя как страну - транзитера российского газа через Украину. Тем самым главная цель правительства А. Дуда - сделать Польшу энергетическим хабом в ЦВЕ и Юго-Восточной Европе. Партия «Право и справедливость» Я. Качиньского - это партия националистов и евроскептиков, действия которой идут вразрез с политикой мультикультурализма А. Меркель. Укрепляя союз с США, Польша стремится как ослабить позиции немецкого капитала на польском внутреннем рынке, так и, в противовес Германии, не только позиционировать себя как самостоятельного лидера Восточной Европы, но и стать главным американским партнером в рамках всего ЕС.

Польско-германские разногласия убедительно доказывают невозможность проведения единой сплоченной европейской политики евро-атлантизма. Наметившаяся трансформация модели внешнеполитического курса ЕС лавирует между укреплением отношений с США в новой интеграционной динамике и желанием европейцев стать самостоятельным актором мировой политики. Данная трансформация, на наш взгляд, сужает возможности американо-германского диалога в области стратегического сотрудничества, ослабляя позиции как США, так и ФРГ. Современная американская дипломатия не оставляет Германии шансов для реализации взаимовыгодного компромиссного решения проблем стратегического партнерства.

\section{Список литературы}

Воробьева Л.М. 2000. Внешняя политика ФРГна пороге ХХІвека. М.: Российский институт стратегических исследований. 356 с.

Троицкий М.А. 2004. Трансатлантический союз. 1991-2004. М.: НОФМО. 252 с. US-German Economic Cooperation: Conflicts, Cooperation, Harmonization (ed. by D. Stiftung). 2003. Berlin, Beuth Verlag GmbH. 138 p.

NOCHVINA Bella Anatol'evna, Cand.Sci. (Hist.), Associate Professor of the Chair of History, Regional Studies and Journalism, Dobroljubov State Linguistics University of Nizhny Novgorod (31a Minina St, Nizhny Novgorod, Russia, 603155; bella.nochtvina@mail.ru)

\section{MODERN US-GERMAN RELATIONS: THE CRISIS OF STRATEGIC PARTNERSHIP}

\footnotetext{
Abstract. The article is devoted to the analysis of the modern strategy of mutual partnership between Germany and the United States in the conditions of aggravation of the situation in the field of nuclear disarmament and strategic stability. A number of European countries assess Germany's current foreign policy as a threat of German hegemony in Europe. The article deals with the potential of the effectiveness of Germany foreign policy doctrine, attempts to assess the prospects of Germany's economic security in the framework of the crisis of Euro-Atlantic model and the optimal means of its implementation. The author analyzes the possibility of the US-German dialogue in the field of strategic cooperation, as well as the transformation of the model of the EU foreign policy as a whole.

Keywords: national security, strategic partnership, Euro-Atlantism, hegemonism, world economy
} 